\title{
SOME BEES OF THE GENUS NOMADA FROM WASHINGTON STATE.
}

\author{
By T. D. A. Cockerell. \\ The University of Colorado.
}

Nomada mutans sp. nov.

q. Length about $7 \mathrm{~mm}$; black with creamy-white markings, and hardly any hair; anterior coxæ without spines; head and thorax strongly punctured; head broad, with the following light markings: lateral marks, broad below, with a little notch on each side near to black part of clypeus, extending upward above level of antennæ, ending in a rather obtuse point, a little away from orbital margin; lower two thirds of clypeus, the margin of the light area broadly angled in the middle above; labrum, but the lower half suffused with reddish; basal half of mandibles (apical half reddish); and narrow posterior orbits; mandibles simple; second joint of labial palpi much less than half length of first; scape blackish behind, reddish in front, with an obscure yellowish mark; flagellum thick, dark reddish above, light ferruginous below, first joint paler; third antennal joint conspicuously longer than fourth; mesothorax shining between the strong punctures; light markings of thorax as follows: upper margin of prothorax, tubercles, tegulæ, scutellum, postscutellum, and a triangular spot on anterior part of pleura; scutellum little elevated; wings dusky, stigma ferruginous, nervures fuscous; $t$. $m$. a short distance basad of b. n.; first $r$. n. reaching second s. m. well beyond middle; legs black, with creamy-white spots on hind coxæ, apices of femora and apices and bases of tibiæ; anterior legs light ferruginous in front; middle legs nearly the same; hind femora with a reddish stripe; anterior tarsi entirely pale reddish; spurs white; abdomen very minutely punctured, with five entire broad creamy-white bands, the first with a pair of spots; band of silver-white hair on fifth segment rather narrow; venter with light bands.

Var. a. Postscutellum all black; band on first abdominal segment without enclosed spots, but with a ferruginous notch on each side behind.

Var. b. Smaller, length about $51 / 2 \mathrm{~mm}$. ; lateral marks not extending above antennæ; scutellum with two large light spots; postscutellum black; fourth and fifth abdominal bands broadly excavated in front on each side.

Hab.- Pullman, Washington State, 1908 (W. M. Mann). Two typical, Aug. 9; one var. a., Aug. 9; two var. b., Aug. 9 and 30 . A 
distinct little species, related to $N$. verecunda Cresson, but easily known by its creamy-white markings. The general appearance is suggestive of $N$. vierecki Ckll., but that has red legs. I wished to name this after its discoverer, but there is already a Nomada manni Morawitz.

\section{Nomada semisuavis sp. nov.}

o. Length about $9 \mathrm{~mm}$; black and bright lemon yellow; the anterior coxæ with long spines; third antennal joint much longer than fourth; $b . \mathbf{n}$. meeting t. m. Almost exactly like $N$. suavis Cresson, and possibly only a race or variety, but having the following distinctive characters: Scape swollen; lateral face-marks broader above; no black between lateral and supraclypeal marks; second s. m. narrower, receiving the first $r$. $n$. at its middle; yellow patch on pleura very large (fully twice as large as in suavis); legs seen from in front entirely yellow, anterior and middle femora with a black band behind, middle tibiæ with a black mark behind, hind femora almost entirely black behind, their tibiæ with a large black longitudinal band; last joint of hind tarsi bright ferruginous; apical plate of abdomen strongly and sharply notched (entire in suavis). $N$. suavis has been referred (Canad. Entom., 1905, p. 283) to Holonomada, but it belongs with the new species in the subgenus Micronomada. Both have in the male a pair of large yellow patches on the metathorax; Cresson's supposed male of $N$. suavis, without these marks, was probably $N$. formula Viereck.

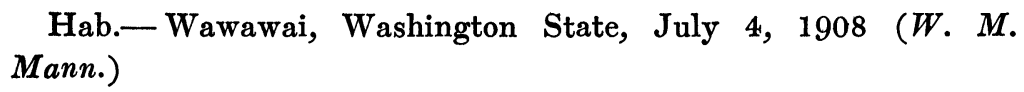

\section{Nomada civilis spokanensis subsp. nov.}

9. Length about $111 / 2 \mathrm{~mm}$; similar to the Corvallis, Oregon, form of $N$. civilis, but differing as follows: Scape wholly light red; tegulæ reddish (instead of yellow); mark on pleura suffused with red, and reduced, its posterior lobe obsolete or almost; yellow on scutellum reduced, with a median black line; metathoracic marks reddish, very small; yellow of legs mainly replaced by red; apical half of first abdominal segment red, with a small obscure yellowish spot on each extreme side; second and third segments very broadly red in the middle. The nervures and stigma are bright ferruginous, and the second submarginal cell has the characteristic broad form, with the r. n. joining it beyond the middle. (The venation indicates its relationship with $N$. civilis, and distinctness from the rather similar $N$. vicinalis aldrichi Ckll.)

Compared with the Colorado form of $N$. civilis it is still more distinct, being much larger, with the bases of the abdominal segments 
broadly black, all the femora and tibiæ with large black patches behind, etc. In the table of Rocky Mountain species (Bull. 94, Colo. Exp. Sta.) it runs to 62 , and runs out because it is a female with black thorax. The hair of the head and thorax above is strongly reddish. The b. $n$. goes a considerable distance basad of $t$. $m$.

Hab.-Spokane, Washington State, May 30 (W. M. Mann). Among the European species, this insect has a strong superficial resemblance to $N$. ruficornis (specimen from Buda compared).

\section{Nomada malonella sp. nov.}

${ }^{0}$. Length about $7 \mathrm{~mm}$; head and thorax black, densely and very coarsely punctured, with white hair, which is dull and scanty above, clear white and more abundant below, abundant and shining on lower part of face; head transversely suboval, face very broad, eyes converging below; lower corners of face, extreme lower margin of clypeus and base of mandibles yellow; mandibles simple, apical half ferruginous with the apex black or almost; labrum black, pallid around the margins; scape stout, wholly black; third antennal joint shorter than fourth, but more than half its length; flagellum long, rather thick, black above, broadly ferruginous beneath; area of metathorax rugose; tegulae dark ferruginous, coarsely rugosopunctate; wings moderately dusky, the large stigma and nervures dark ferruginous; b. n. going far basad of t. m.; second s. m. broad above; legs red, the femora and tibiæ largely black behind, the posterior ones almost wholly so; hind tarsi largely blackened; spurs white; abdomen narrow, light but dullish red, with fine whitish pubescence giving it a silky appearance; first segment with the basal half black, the other segments a little blackened at extreme base; extreme side of segments 2 to 5 , with successively smaller cream-colored spots; segments 4 to 6 with also subdorsal spots; venter with imperfect cream-colored bands, out of which large pieces seem to have been cut at the sides. Allied to $N$. elegantula Ckll. and somewhat to $N$. melliventris Cresson.

\footnotetext{
Hab.- Wawawai, Washington State, May 1, 1909 (W. M. Mann).
}

A female (date and locality the same) seems to belong here, but may represent another species. It is only about $61 / 2 \mathrm{~mm}$. long, and differs from the male thus: Scape with a red spot at base; third antennal joint almost as long as fourth; thorax with red marks as follows: upper border of prothorax, tubercles, two fine lines on mesothorax, two spots on scutellum, axillar spots, a line on postscutellum, a spot beneath wings, and a transverse mark on 
lower part of pleura; also other minor details. There is a small red spot above each eye. The upper side of the abdomen agrees with that of $N$. angelarum Ckll.

\section{Nomada malonina sp. nov.}

$\sigma^{3}$. Length about $5 \% 4 \mathrm{~mm}$; looks at first sight like a small example of $N_{t}$ malonella, but differs as follows: Flagellum proportionately shorter; lower margin of clypeus broadly yellow at sides; light parts of legs paler and suffused with yellowish; hind legs black except the knees, and apices of the other joints; $t$. m. a little basad of b. n.; scutellum less prominent; ground-color of abdomen light yellowish-red; first segment with more than basal half black, the edge of the black rather concave in the middle (projecting to form an angle in malonella); fourth and following segments dark with a subapical yellow band; sides of segments 2 to 4 with a broad oblique light yellow band, on 2 and 3 with a dark patch in front; ground color of venter dark, and light bands much broader. In both species the apical plate is strongly notched.

Hab.-Wawawai, Washington State, May 15, 1909 ( $W . M$. Mann).

The following table separates the four related species. The venation of $N$. melliventris was kindly noted for me by Mr. Viereck, from Cresson's type.

Basal nervure going far basad of transversomedial...............

Basal nervure falling a little short of transversomedial...........

1. Tegulæ dark reddish; labrum black, except margins; scutellum prominent.................................... malonella $\sigma^{n}$

Tegulæ yellowish; labrum yellow; scutellum not prominent, melliventris $\sigma^{\circ}$

2. Scape with a large red basal patch in front; ground color of abdomen bright coppery-red............................elegantula $q$ Scape wholly black; ground color of abdomen pale yellowish-red

malonina $\sigma^{\circ}$

Nomada (Gnathias) perplexans sp. nov.

$\checkmark$. Length about $9 \mathrm{~mm}$; head and thorax black, with long coarse white hair, which is slightly stained with yellowish above; lower corners of face sending a linear process along orbits nearly to level of antennæ, clypeus except sides above, labrum and basal half of mandibles, all light yellow; scape entirely black; flagellum red, the first five joints black above, the others with a blackish band; third antennal joint a little shorter than fourth; thorax densely and strongly punctured, 
wholly black except the reddish tubercles; tegulæ very bright ferruginous; wings strongly dusky at apex; stigma ferruginous, nervures fusco-ferruginous; b. n. going far basad of t. m.; first r. $n$. joining second s. m. well beyond middle; legs red, the anterior femora black at base behind, the other femora with more black, the hind ones with more black than red; abdomen clear red, first segment with basal half and a pair of spots on apical half black; second segment with a pair of very large pale yellow patches, pointed mesad; sixth with a pair of obscure yellowish spots; apical plate notched; venter red with broad suffused blackish bands. A western representative of $N$. perplexa Cresson, easily distinguished by the much lighter red abdomen.

Hab.- Pullman, Washington State, June 7, 1908 (W. M. Mann).

Nomada itamera sp. nov.

9. Length $81 / 2 \mathrm{~mm}$; head and thorax coarsely rugosopunctate, with scanty white (yellowish dorsally) hair; black, with the following parts dark red, face below antennæ except a broad black band extending from each antenna to clypeal margin, mandibles (which are stout and blunt, but entire) entirely, labrum, posterior orbits extremely narrowly, a large triangular mark above each eye, a large V-shaped mark on each side of mesothorax, the greater part of the extremely prominent and strongly bilobed scutellum, upper border of prothorax, tubercles, and a very large patch on pleura; antennæ thick, third joint shorter than fourth, scape red in front, flagellum dark red suffused with dusky; tegulæ very bright ferruginous, strongly punctured; wings very dark on apical margin, stigma and nervures dark reddish; b. n. going a moderate distance basad of t. m.; second s. m. large, receiving first $r$. $n$. at middle; legs red, the femora with much black, the edges of the black suffused; abdomen broad, dark red, black at base of first segment trilobed, apical margin of first two segments strongly blackened; apical half of abdomen darker, with minute scattered glittering hairs; sides of second segment with a round suffused yellow spot; fourth segment with a pair of subdorsal yellow spots.

Hab.- Pullman, Washington State, May 30 (W. M. Mann). There is no sign of yellow at lower corners of face. A probable male of this species is from Wawawai, May 15 .

Nomada orcusella sp. nov.

9. Length $81 / 3 \mathrm{~mm}$; ; bright ferruginous; head and thorax rugosopunctate; eyes reddish-grey; a keel between antennæ; the following parts are black, a large patch on front, including antennal sockets, a small area about ocelli; cheeks posteriorly, a median stripe on mesothorax, a 
stripe on metathorax, area between wings and middle and hind legs, and region round tubercles; third antennal joint shorter than fourth; scape red; flagellum entirely red; scutellum bigibbous; tegulæ bright ferruginous, punctured; wings strongly dusky, with a hyaline area beyond submarginal cells; stigma dark ferruginous, nervures dark fuscous; b. n. going far basad of t. m.; first r. n. entering second s. m. much beyond middle; legs red, hind femora with much black, the others with some at base; hind basitarsus suffused with blackish; abdomen shining bright ferruginous, the segments not at all darkmargined, first segment black at extreme base and half-way along sides in second segment, with a large yellow spot on each side, third with very small spots; apical segments without yellow; venter without yellow. The mandibles are simple, and there is no yellow at lower corners of face.

Hab.- Orcus Island, Washington State, latter half of July, 1909 (W. M. Mann). The following table separates several females of Nomada s. str. described from Washington State:

Abdomen without yellow spots................kincaidiana Ckll.

Abdomen with yellow spots, at least on second segment............

1. Metathorax black, except for a couple of hardly visible red spots on enclosure; abdomen with scanty short silvery hairs, shining in certain lights...................................

Metathorax red with a central black band; abdomen without shining

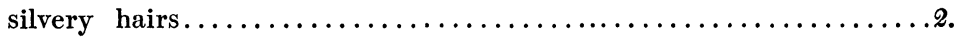

2. Abdomen deep chestnut red; wings darker........... orcusella Ckll.

Abdomen light red....................... flammigera Ckll.

The Nomadæ of Washington State were listed and tabulated by Viereck in Canadian Entomologist, Aug. 1905. A collection received from Mr. W. M. Mann contains not only the new forms described above, but also several others new to the state, so it will be worth while to give a new list, complete to date. I have omitted from it some males of Nomada s. str., which probably belong with females already described, but cannot be certainly associated with them at present.

\section{Gnathias.}

This group differs from all the others in having bidentate mandibles.

(1.) N. perbella Viereck. Hoquiam (Burke, fide Viereck); Olympia and Seattle (Kincaid, fide Viereck); Wawawai, May 1, both sexes (Mann); Pullman, May (Mann). 
Mr. Mann's specimens have the abdomen dark red, and agree with Viereck's description in both sexes. On this basis, the species seems valid; but the Kincaidian specimens, which I formerly (Proc. Acad. Nat. Sci. Phila., 1903, p. 601) referred to $N$. bella Cresson, have the female paler than in typical bella, and do not seem to be perbella. More collecting is needed to determine whether there are really two species.

(2.) N. perplexans, n. sp. Pullman (Mann).

(3.) N. cuneata Robertson. Pullman, May (Mann). This is not quite typical; from a single specimen I cannot determine whether there is a distinct northwestern race.

(4.) N. grayi eastonensis Ckll. Easton.

(5.) N. washingtoni Ckll.

\section{Nomada s. str. (Robertson.)}

Like Gnathias but with simple mandibles.

(6.) N. flammigera Ckll. N. Yakima (Jenne); see Ann. and Mag. Nat. Hist., July, 1906, p. 71.

(7.) N. cressoni trevoriana Ckll. Olympia (Kincaid).

(8.) N. kincaidiana Ckll.

(9.) N. itamera n. sp. Pullman (Mann).

(10.) N. orcusella n. sp. Orcus I. (Mann).

(11.) N. malonella n. sp. Wawawai (Mann).

(12.) N. malonina n. sp. Wawawai (Mann).

(13.) N. packardiella Ckll., var. a. Mesothorax with three black stripes; a large yellow patch on fifth abdominal segment. Pullman, May 14, 1909 (Mann).

(14.) N. pulsatilloe Ckll., var. a. Silvery apical lunule on abdomen larger. Pullman, May 2, Spokane, May 30, and Wawawai, May 1 (Mann).

(15.) N. vicinalis aldrichi Ckll. Spokane, May 30 (Mann).

\section{Xanthidium.}

(16.) N. citrina Cresson.

(17.) $N$. rivalis Cresson.

(18.) N. civilis Cresson. Males with scutellum all dark. Wawawai, April 24 to May 15, and Pullman, May 20 (Mann).

(19.) N. civilis spokanensis n. subsp. Spokane (Mann).

(20.) N. modocorum Ckll. Spokane, May 30 (Mann).

(21.) N. coquilletti Ckll. Wawawai, March and April (Mann).

The characters originally given to separate $N$. coquilletti from $N$. modocorum are not constant; the Washington State specimens separate as follows: 
(a.) Abdomen red, yellow and black; tegulæ red; scutellum with two red spots; metathorax without spots; legs red and black.

(a.) Larger (and with other differences) $N$. vicinalis aldrichi

(b.) Smaller......................... modocorum

(b.) Abdomen black and yellow, with a little reddish; legs yellow, red and black; tegulæ yellow, at least in part; scutellum, postscutellum and metathorax black............. coquilletti $0^{*}$

(22.) N. pascoensis Ckll. Pasco (Kincaid); Wawawai, May 15 (Mann).

(23.) N. jennei Ckll. N. Yakima (Jenne). Not a true Xanthidium; there is apparent affinity with Micronomada; see Canad. Entom., 1906, p. 282.

\section{Holonomada.}

(24.) N. hesperia Ckll. Pullman, May 15 and 23, 1909 (Mann). One is much smaller than the other.

(25.) N. edwardsii Cresson. Pullman, June 1 (Mann).

(26.) N. vinnula Cresson. Spokane, May 20, Wawawai, May 15, and Pullman, May 23 (Mann).

(27.) N. mutans n. sp. Pullman (Mann).

\section{Micronomada.}

(28.) N. semisuavis n. sp. Wawawai (Mann).

\section{Nomadula.}

(29.) N. articulata Smith. Pullman, May 28 (Mann).

(30.) N. erythrochroa Ckll. Pasco (Kincaid); N. Yakima, June (Jenne). 

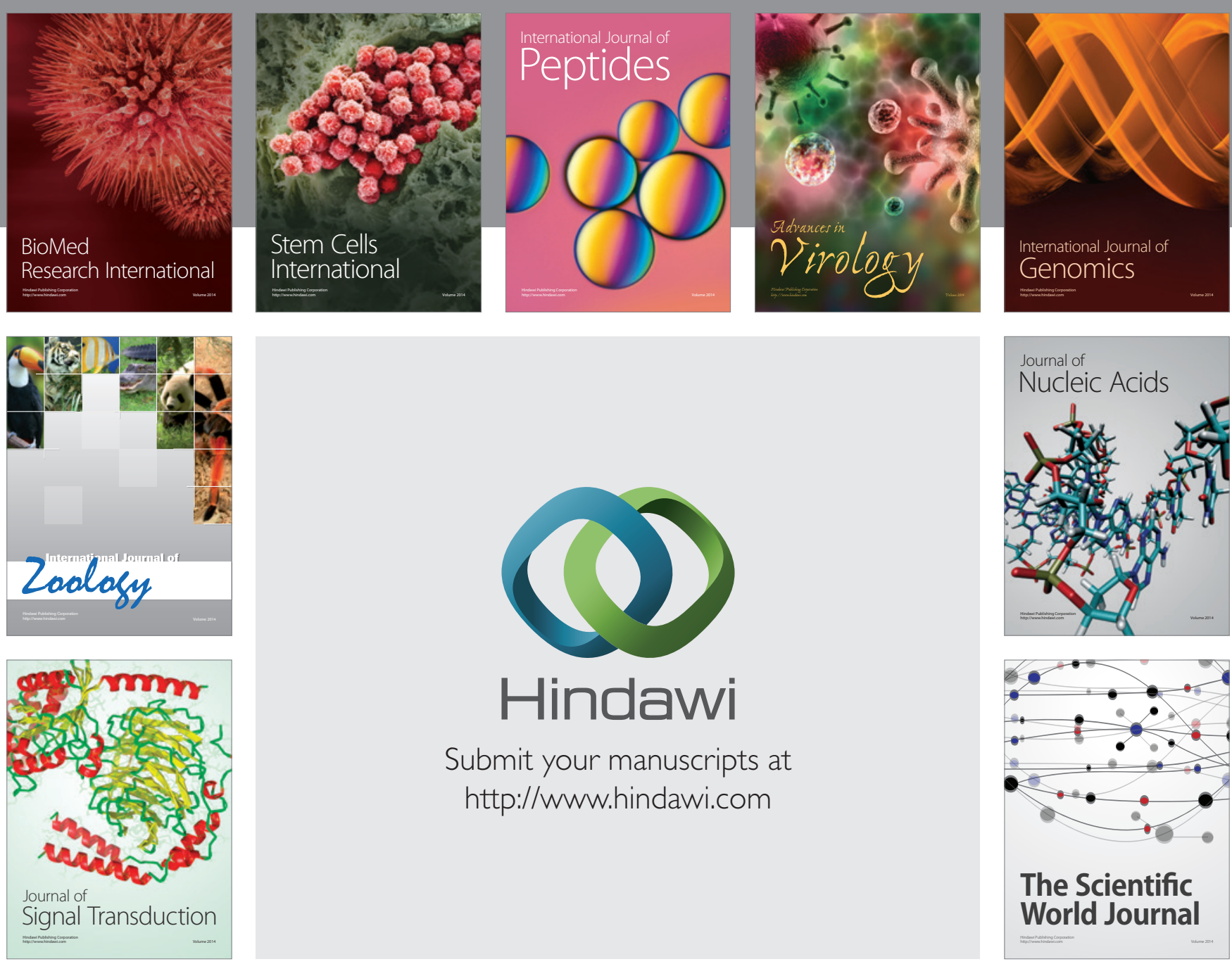

Submit your manuscripts at

http://www.hindawi.com
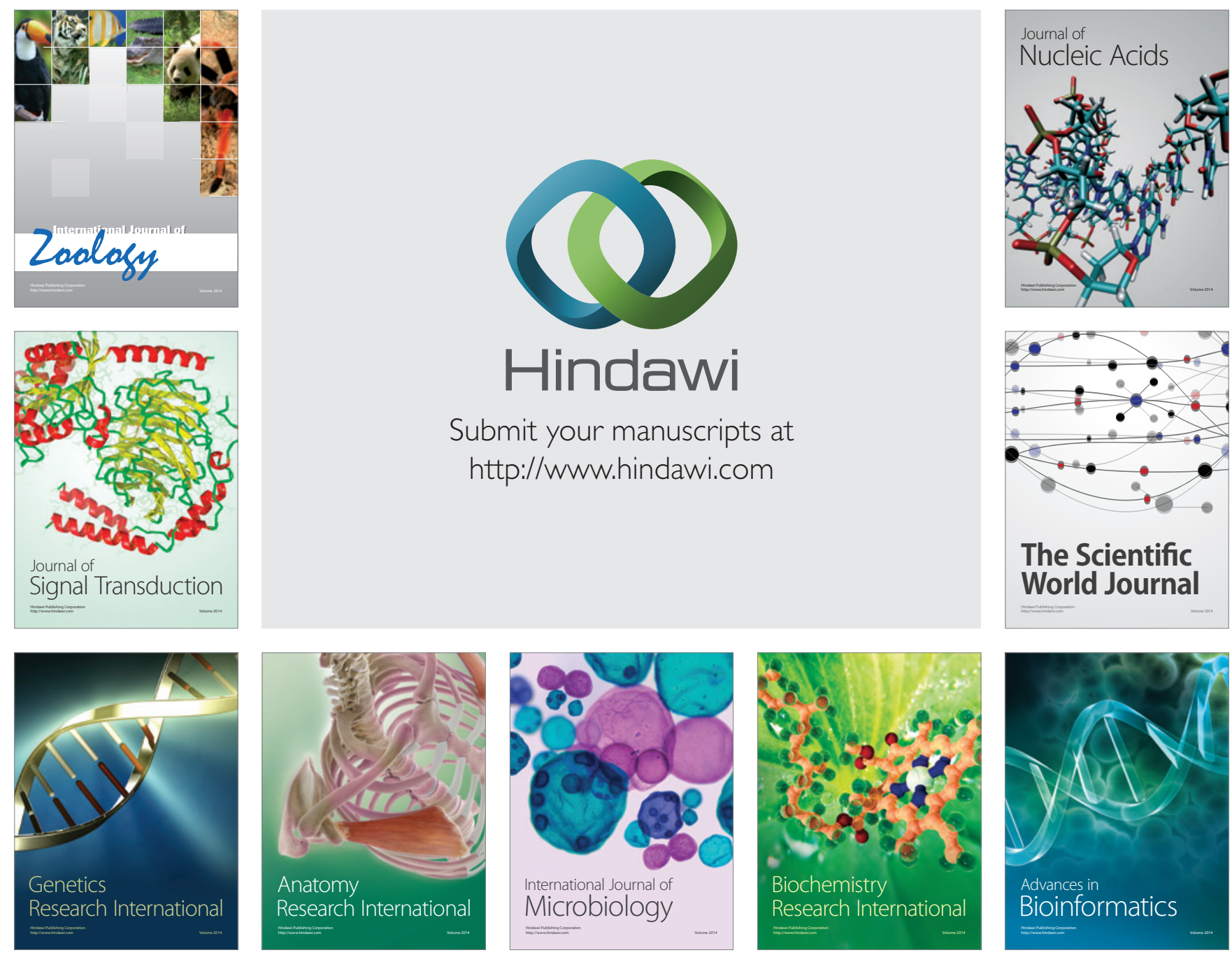

The Scientific World Journal
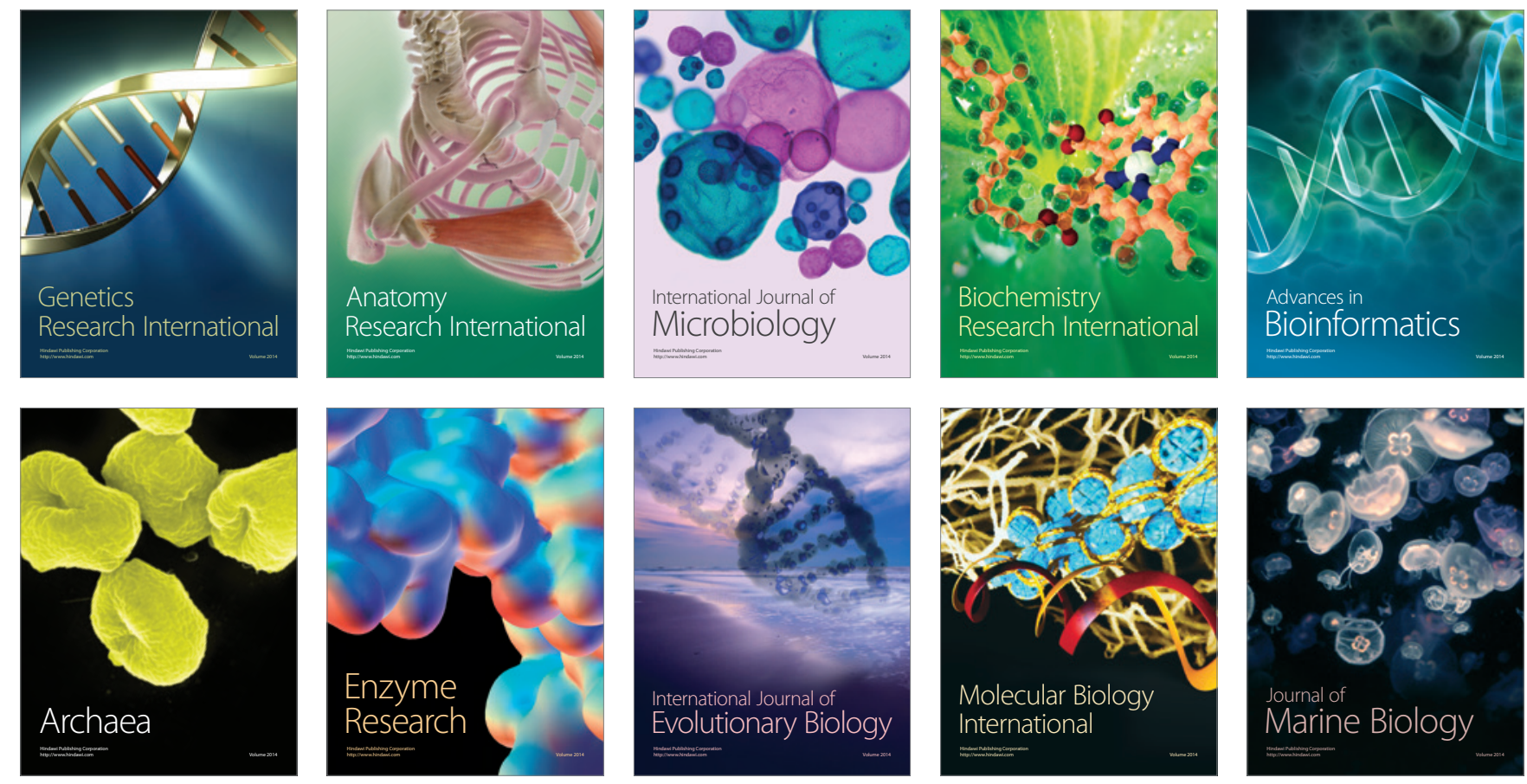